\title{
リブを有する平行平板間乱流熱伝達の DNS \\ DNS of turbulent heat transfer in a channel flow obstructed by square ribs
}

\author{
○村 英雄（東理大院） 正 関 洋治（東理大院） \\ 正 河村 洋 (東理大) \\ Fusao KAWAMURA, Yohji SEKI and Hiroshi KAWAMURA, \\ Dept. Mech. Eng., Tokyo Univ. of Science, Noda-shi, Chiba
}

\begin{abstract}
Direct numerical simulation has been performed for the turbulent heat transfer in a channel flow obstructed by square ribs at $\operatorname{Re}_{\tau}=80$ and $\operatorname{Pr}=0.71$. The constant wall temperature difference was applied between the walls for thermal boundary condition. The remarkable enhancement of the heat transfer is observed through the averaged Nusselt number $N u$ by comparison with the channel flow without the ribs. In particular, the local $\mathrm{Nu}$ increases around the upstream of the rib owing to the existence of the strong horseshoe vortices. The thermal turbulence statistics and the visualization of the instantaneous temperature fluctuations are also obtained to examine the effect of the ribs on the thermal field.
\end{abstract}

Key Words: DNS, Turbulent Heat Transfer, Channel Flow, Ribs

\section{1. 緒言}

発熱するチャネルからの除熱設計においては，発熱体温 度と冷却材の出口温度の双方を目標値に設定することが同 時に重要であることが多い。このためには, 冷却材のレイ ノルズ数を可能な限り低い值に抑えつつ, 乱流を維持する 必要が生ずる場合もある，そこで本研究では，低レイノル ズ数のチャネル内乱流における熱伝達において, 通常の粗 面要素よりも大きな突起物を配置することにより, 極めて 低いレイノルズ数までの乱流の維持し, かつ熱伝達の促進 効果をもたらすことを目的として直接数值シミュレーショ ン（DNS）を実施した。

流路内における強制対流熱伝達の促進に関しては, 粗面 を利用する方法 ${ }^{(1) \sim(3)}$, 流路内に乱れ促進体を設置する方法 (4)〜(6)などが挙げられる. 本研究では, 環状流路内にスペー サーが存在することを想定し, 平行平板間に周期的に角柱 のリブが存在する場合を考える. 低いレイノルズ数におい て, リブを有する十分発達した平行平板間乱流熱伝達の解 析をDNSにより行い, リブが温度場に与える影響を明らか にし，伝熱促進効果について検討する。

\section{2. 解析対象及び計算手法}

計算対象の概略図を Fig. 1 に示寸。上下壁面に接する角 柱のリブを平行平板の間に設置した．流れは平均圧力勾配 により駆動される．流れ方向及びスパン方向には周期境界 条件を, 壁面では non-slip 条件を課し, リブは Immersed Boundary Methodにより再現した。温度の境界条件として 上下壁面温度差一定条件 (CTD) を課し, 下壁面で $T^{*}(=T$ $(\Delta T)=1$ ，上壁面で $T^{*}=0$ とした．また，リブ内部におい ては, 周囲の流体に比べ熱が非常に伝わりやすいと仮定し, リブ表面において，下壁面から上壁面まで線形的な温度分 布を与えた。

支配方程式は，非圧縮性流体の連続の式，Navier-Stokes 方程式及びエネルギー方程式である。連続の式と Navier-Stokes 方程式のカップリングには FS 法を用いた. 時間積分には，粘性項の $y$ 方向に二次精度 Crank-Nicolson 法を, それ以外の項には二次精度 Adams-Bashforth 法を用 いた. 空間的離散化には, $x, z$ 方向に四次精度中心差分を, $y$ 方向には二次精度の中心差分を適用した。摩擦レイノル ズ数 $\operatorname{Re}_{\tau}\left(=u_{\tau} \delta / v\right)$ は 80 とし, プラントル数 $\operatorname{Pr}$ は 0.71 と した.ここで， $u_{\tau}$ は流れを駆動する平均圧力勾配より定義 される壁面摩擦速度, $\delta$ はチャネル半幅, $v$ は動粘性係数
である、計算条件を Table 1 に示す

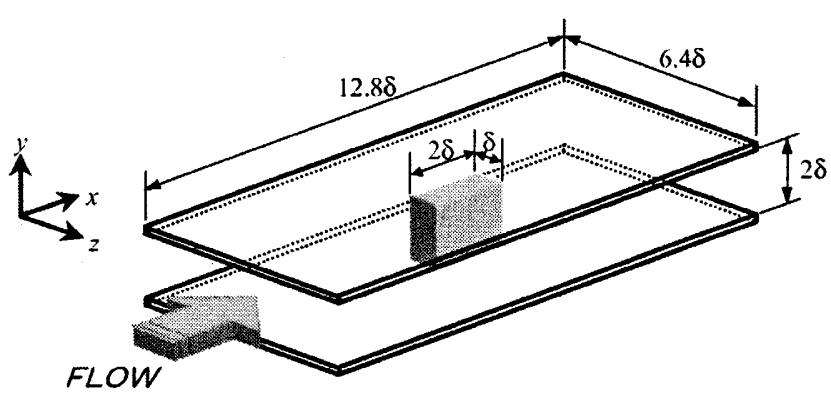

Fig. 1 Configuration.

Table 1 Computational condition.

\begin{tabular}{lc}
\hline \hline Computational Volume $\left(L_{\mathrm{v}} / \delta \times L_{y} / \delta \times L_{z} / \delta\right)$ & $12.8 \times 2 \times 6.4$ \\
Computational Volume $\left(L_{x}^{+} \times L_{y}^{+} \times L_{z}^{+}\right)$ & $1024 \times 160 \times 512$ \\
Grid Number $\left(N_{x} \times N_{y} \times N_{z}\right)$ & $256 \times 128 \times 256$ \\
Spatial Resolution $\left(\Delta x^{+}, \Delta z^{+}\right)$ & $4.00,2.00$ \\
Spatial Resolution $\left(\Delta y^{+}\right)$ & $0.17 \sim 2.64$ \\
Time Resolution $\left(\Delta t^{+}\right)$ & 0.0136 \\
\hline \hline
\end{tabular}

\section{3. 結果及び考察}

3.1 平均温度分布

$z / \delta=3.2$ の $(x, y)$ 平面における平均温度分布を Fig. 2 に示 す.リブ前方では等温線の分布から，チャネル中央付近の 温度が上下壁面近傍まで輸送されていることがわかる。こ れは，リブに衝突した流体がチャネル中央付近から上下壁 面に向かって流れ込んでいるためである(7). リブ後方の $y$ 方向平均温度分布について見ると, リブ表面付近では境界 条件の影響により線形的であるが，下流へ行くにしたがっ て,チャネル中央高さ付近の等温線の間隔が広がっている. これは, リブ後方 $(x / \delta=8.6 \sim 11.5)$ における複雑な流れ場 により温度場がよく混合され，さらに下流において，チャ ネル中央の平均温度が均一になるためである。

\section{2 温度バリアンス}

温度バリアンス $k_{\theta}{ }^{*}$ の分布を Fig. 3 に示す. Fig. 3 (a) に おいて, 壁面近傍の温度勾配の大きい領域で温度バリアン スが大きくなっている.さらに特徴的なのは, リブ背面の 上下壁面付近 $(x / \delta=7.4 \sim 8.5)$ で $k_{\theta}{ }^{*}$ の大きい領域が存在す ることである。これは，リブ後方にチャネル中央へ巻き上 げる渦が存在し(7), それに起因した大きい温度変動が存在 しているためである. また, リブ後方 $(x / \delta=8.6 \sim 11.5)$ の 
チャネル中央高さ付近においても $k_{\theta}{ }^{*}$ の大きい領域が存在 する.これは Fig. 2 に見られるように，この領域で温度勾 配が大きいためである. Fig. 3(b) でも観察されるように, チャネル中央付近における $k_{\theta}^{*}$ の值は, $x / \delta=11.5$ 以降から リブ前面にかけて小さい.これは, 平均温度分布において, リブ後流の混合作用によりチャネル中央の平均温度勾配が 次第に小さくなることに対応している.

\section{3 温度変動の瞬時場}

温度変動の瞬時場を Fig. 4 に示す. 全体的に比較的大規 模な温度変動がチャネル中央で多く観察される．これは平 滑なチャネルにおける CTD の場合と同じ傾向である ${ }^{(8)}$. 本 研究ではレイノルズ数が低いため, チャネル中央の大規模 な構造と壁面近傍のストリーク構造のスケールは同程度と なっている. また, リブ後方 $(x / \delta=8.6 \sim 11.5, z / \delta=1.6 \sim 4.8)$ で観察される細かい温度変動は，混合の強い領域を示して いる.

\section{4 局所ヌッセルト数 $N u$ 分布}

下壁面における $N u$ の分布を Fig. 5 に示す. リブ前方の 馬蹄渦の存在する領域において ${ }^{(7)} N u$ が最も大きくなる.こ れはチャネル中央付近の比較的低温の流体が壁面近傍まで 流れ込み，壁面上における温度勾配が大きくなるためであ る. Fig. 6 に平滑流路におけるバルクレイノルズ数 $R_{m}(\equiv$ $\left.u_{m} \cdot 2 \delta / v\right)$ に対する $N u$ の関倸を示す ${ }^{(9)}$.ここで, $u_{m}$ はバ ルク平均速度である. 本研究ではリブの形状抵抗の影響で $R e_{m}$ は 1120 と小さくなった. しかし, 平均ヌッセルト数 $N u_{a v e}$ は 7.2 となり, 同じ $R e_{m}$ における平滑流路の $N u$ に比 べ，大きい值となった．流路全体で見ても熱伝達が促進さ れていることがわかった。

\section{4. 謝辞}

本研究結果は, 東北大学情報シナジーセンター大規模科 学計算システムを利用して得られた.

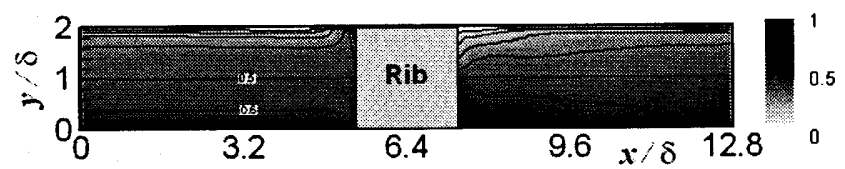

Fig. 2 Contour of the time-averaged temperature $\overline{T^{*}}$

(a)

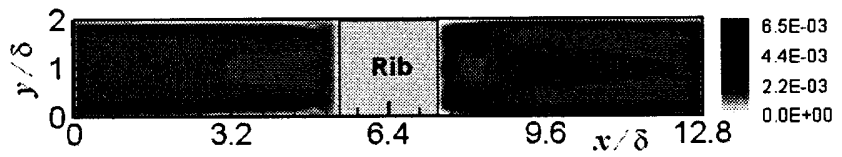

(b)

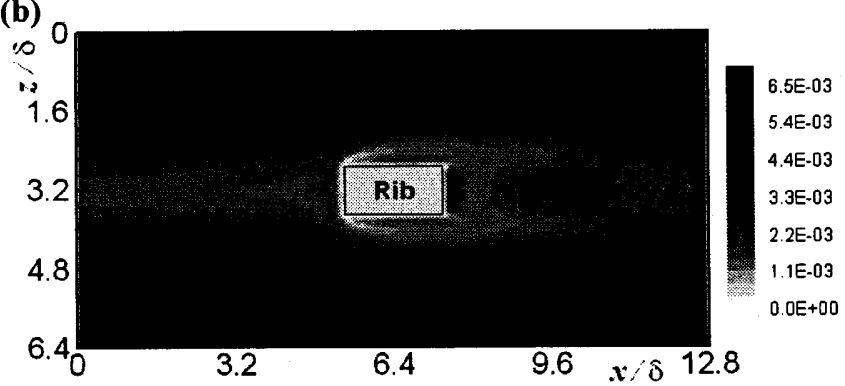

Fig. 3 Contour of the temperature variance $k_{\theta}^{*}\left(=\overline{T^{* / 2}} / 2\right)$

(a) at $z / \delta=3.2$; (b) at the channel center .

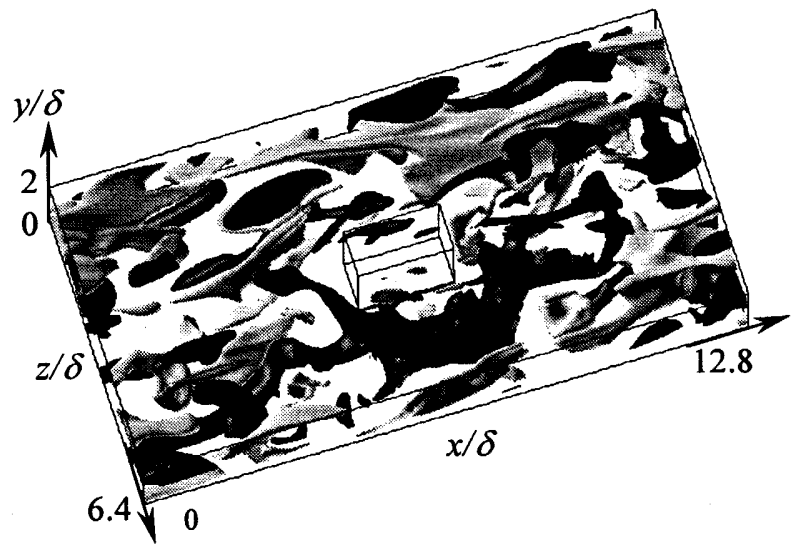

Fig. 4 Iso-surfaces of instantaneous temperature fluctuations in the whole computational domain. The flow direction is from left to right. Dark gray, $T^{* \prime} /\left(T_{\mathrm{rms}}^{*}\right)_{\max }=1$; light gray, $T^{*}$ / $\left(T_{\mathrm{rms}}^{*}\right)_{\max }=-1$.

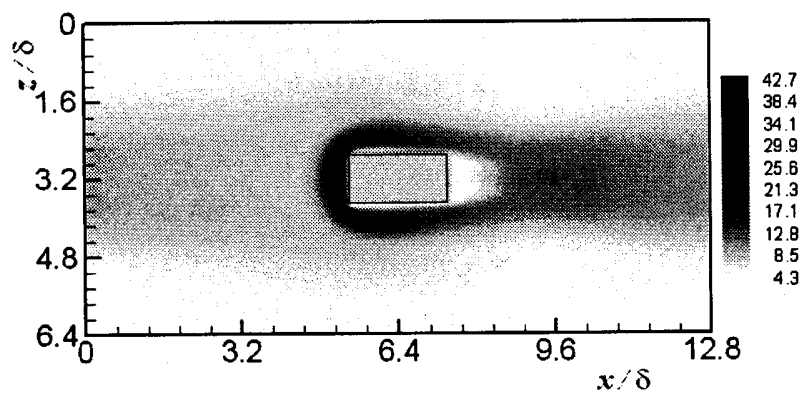

Fig. 5 Contours of local Nusselt number on the bottom wall.

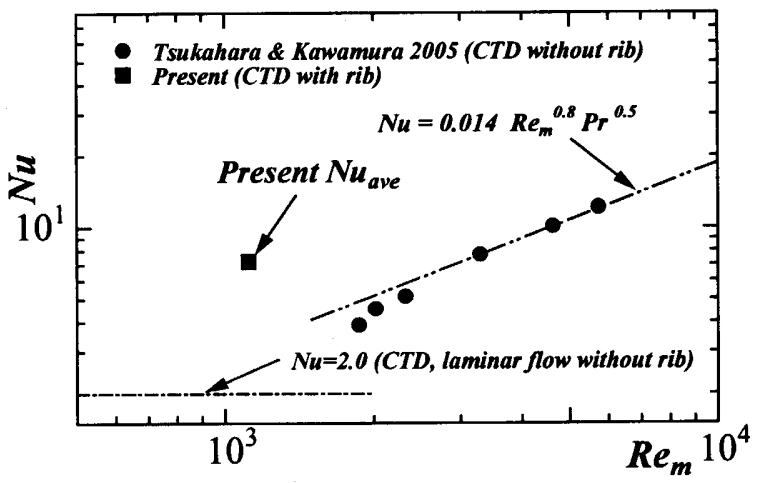

Fig. 6 Nusselt number as a function of bulk Reynolds number.

\section{参考文献}

(1) 廣田ら，機論（B 編），67-653 (2001), 154.

(2)杉山ら，機論（B 編），69-681 (2003), 1051.

(3) Y. Nagano et al., Int. J. Heat and Fluid Flow, 25 (2004), 393.

(4) 矢尾ら，機論（B 編）， 60-576 (1994), 2819.

(5) A. Valencia, Int. J. Heat and Fluid Flow, 42 (1999), 2053.

(6) D-H. Kim et al., Computers \& Fluids, 33 (2004), 81.

(7) 川村ら, 日本流体力学会年会講演論文集 CD-ROM, (2005), AM05-12-010.

（8）関ら，機論（B 編）， 70-696 (2004), 2089.

(9)塚原ら, private communication (2005). 